\title{
The Appropriateness to Use Fixed Assay Cut-Offs for Estimating Seroprevalence [Response to Letter]
}

\author{
Khaled R Alkharsah $\mathbb{D}^{\prime}$, Adel I Al-Afaleq ${ }^{2}$ \\ 'Department of Microbiology, College of Medicine, Imam Abdulrahman Bin Faisal University (IAU), Dammam, Kingdom of Saudi Arabia; ${ }^{2}$ Department \\ of Environmental Health, College of Public Health, Imam Abdulrahman Bin Faisal University (IAU), Dammam, Kingdom of Saudi Arabia \\ Correspondence: Adel I Al-Afaleq, Email aalafaleq@iau.edu.sa
}

\section{Dear editor}

We were glad to read the letter to the editor by $\mathrm{Da}$ et $\mathrm{al}^{1}$ on our study. ${ }^{2}$ This indicates that our study attracted interest and added a value to the scientific community. We thank the colleagues for the constructive points they raised. We do have a common ground on some of the points however; other points were not so accurate. To enrich the scientific discussion, our reply to the raised points is as follows:

1. It is very well expected that the cut-off value affects the sensitivity and the specificity of an assay. Therefore, a fixed and defined rules for setting up the cut-off value should be followed throughout any assay to avoid interlaboratory variations and to make results comparable between different studies. The cut-off value in our assay is based on cut-off calibrators that are run with each experiment. Such procedure further minimizes the intraassay variability contrary to using fixed assay cut-off value that does not take into account the run-to-run variability. We disagree with our colleagues that "there are no definite rules of the choice of the cut-off value". The cut-off value development, its quality control, and its calculation were very well described by the manufacturer. Hence, we felt that it is sufficient to refer the reader to the manufacturer's instructions.

2. We agree with our colleagues on this point. We have stated the limitations of testing for WNV antibodies clearly and in many locations in the paper. We have also discussed these limitations in light of the assay procedures and epidemiological context.

3. As mentioned in the manuscript, our study is the first to estimate the seroprevalence of WNV antibodies in human and pigeons in the country. So, there is no population-based data available. However, the quantitative antibody detection approach is an interesting possibility and could be considered for future studies.

4. To confirm the transmission of WNV through blood donation, we have to confirm the presence of the WNV nucleic acid or its antigens in the donor blood samples, which was out of the scope of our study.

\section{Disclosure}

The authors declare no conflicts of interest in this communication.

\section{References}

1. Da Y, Wu Y, Quan P. The appropriateness to use fixed assay cut-offs for estimating seroprevalence.

2. Alkharsah KR, Al-Afaleq A. Serological evidence of West Nile virus infection among humans, horses, and pigeons in Saudi Arabia. Infect Drug Resist. 2021;14:5595-5601. doi:10.2147/IDR.S348648 
Dove Medical Press encourages responsible, free and frank academic debate. The content of the Infection and Drug Resistance 'letters to the editor' section does not necessarily represent the views of Dove Medical Press, its officers, agents, employees, related entities or the Infection and Drug Resistance editors. While all reasonable steps have been taken to confirm the content of each letter, Dove Medical Press accepts no liability in respect of the content of any letter, nor is it responsible for the content and accuracy of any letter to the editor.

Infection and Drug Resistance

Dovepress

\section{Publish your work in this journal}

Infection and Drug Resistance is an international, peer-reviewed open-access journal that focuses on the optimal treatment of infection (bacterial, fungal and viral) and the development and institution of preventive strategies to minimize the development and spread of resistance. The journal is specifically concerned with the epidemiology of antibiotic resistance and the mechanisms of resistance development and diffusion in both hospitals and the community. The manuscript management system is completely online and includes a very quick and fair peer-review system, which is all easy to use. Visit http://www.dovepress.com/testimonials.php to read real quotes from published authors.

Submit your manuscript here: https://www.dovepress.com/infection-and-drug-resistance-journal 